\title{
2 歳齢保育園览の向社会的なやり取り
}

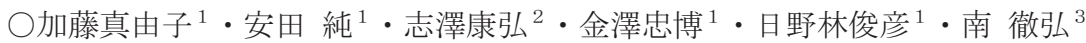 \\ ( 1 大阪大学大学院人間科学研究科・2 平安女学院大学・ 3 大阪成蹊短期大学) \\ キーワード: 向社会的行動、2 歳齢保育園児、やり取り
}

\begin{abstract}
Two-year-old preschoolers' prosocial responses to their peers' distress
Mayuko KATO $^{1}$, Jun YASUDA ${ }^{1}$, Yasuhiro SHIZAWA ${ }^{2}$ Tadahiro KANAZAWA ${ }^{1}$, Toshihiko HINOBAYASHI ${ }^{1}$, and Tetsuhiro MINAMI ${ }^{3}$ ( ${ }^{1}$ Graduate School of Human Science, Osaka Univ., ${ }^{2}$ St. Agnes' University, ${ }^{3}$ Osaka Seikei College)

Key words: prosocial behavior, Two-year-old preschoolers, interaction
\end{abstract}

\section{目 的}

共感性の起源は生後 1 年目からみられ、最初は他者の苦痛 に気が付くことから始まる。2 歳齢頃には他児の感情的な反 応を認識することができるようになり、苦痛を感じている他 児に物を渡したり、慰めたりすることによって、向社会的に 介入するようになる (Hay et al., 1999)。つまり、児は発達的 に早い段階から他者の苦痛を認識し、助け方を知っていると いえる。そして向社会的に振舞われた児は、向社会的行動を 行った览に対して、親和的な感情を抱き、互恵的関係を形成 し、お互いにより反応しやすくなることが指摘されている。 これらの研究では 3 歳齢以降の児を対象としているが、上で 述べたように児はそれよりも早い段階から苦痛を感じている 他児に対する向社会的行動を示すことが可能である。

本研究においては、集団保育場面において自然的観察を行 い、2 歳齢児が他児の苦痛に接する機会はどの程度みられる か、そして他児の苦痛に直面したとき、児がどのように反応 するのかを記録した。そして児が他児の苦痛に向社会的に関 わった後に、向社会的行動を受けた児との間でどのようなや り取りがなされるのかを検討した。

\section{方 法}

調査対象：大阪市内 $\mathrm{M}$ 保育園に在籍する幼児 17 名（男児 8 名、女児 9 名）を対象とした。観察することに同意を得た児 の中で、観察開始時に 23 力月齢になる览 10 名（男児 6 名、 女児 4 名）を観察対象児とし、対象児が $23 、 24$ 力月齢の間に 調査を行った。

調査手続き：観察は教室内での自由遊び時間に実施された。 観察には、1 名の対象児を一定時間観察し、その児の行動を 継続して記録する観察法を用い、対象児を中心とした半径 1-2 $\mathrm{m}$ の範囲をVTR で記録した。この際、対象児や周囲の他児の 表情についても記録を行うため、対象児の正面または側面か ら撮影するように努めた。以上の手続きにしたがって、1 日 に 1 名の対象児を可能な限り撮影し、 1 名につき 5 日〜 8 日間 観察を行った (平均観察時間 : 444.7 分)。

コーディング：VTRに記録された映像をもとに、対象児の争 いエピソード、泣き行動に対する周りの他児の反応がコーデ イングされた。他児の反応は「攻撃」「からかい」「無反応」 「視線を向ける」「接近し覗き込む」「慰め」の 6 種類に分類し た (Kestenbaum et al. (1989) を参考に作成)。先行研究では「視 線を向ける」「接近し覗き込む」「慰め」を向社会的な反応と していたが、本研究では「接近し哯き込む」「慰め」を向社会 的な反応とみなした。そして他児が「接近し覘き込む」「慰め」 の反応を示した後の 5 分間に、対象児との間にどのようなや り取りがなされたのかも記録した。やり取りの内容は、ポジ ティブな相互交渉とネガティブな相互交渉に分類し、それぞ れの相互交涉の生起頻度を記録した。

\section{結 果}

争いエピソードは計 449 回みられ、その中で泣きは 128 回 みられた（観察対象児 1 名あたり平均 12.8 回 ; レンジ: $3-$ 22 回)。対象児の泣きに対する他児の反応は計 182 回みられ た。泣きに対する他児の反応が泣きの事例数より多いのは、 一つの泣きに対して複数の他児が関わりかけたためである。 泣きに対する他児の反応

対象児の泣きにおいてみられた他児の反応は、「攻撃」が 4.4\%、「からかい」が 0.5\%、「無反応」が 39.6\%、「視線を向 ける」が $33.0 \%$ 、「接近し親き込む」が $16.5 \%$ 、「慰め」が $6.0 \%$ であった。

向社会的行動後のやり取り

泣いている児に対して他児から「接近し覗き込む」と「慰 め」の反応がみられたのは計 41 回であった。その中で、泣い ていた児と向社会的行動を示した児の間で、ポジティブな相 互交渉がみられたのは全体の $17.1 \%$ 、ネガティブな相互交渉 がみられたのは 9.8\%であった。つまり、他児からの向社会的 行動が起こった後に、その二者間での相互交渉は多くの場合 みられなかったといえる。

\section{考 察}

2 歳齢児は他児が泣いている場面で、何も反応しなかった り、泣いている児に視線を向ける反応が非常に多かったが、 接近して覗き込んだり、慰める反応も少数ながらみられた。 この結果から、2 歳齢は他者への視点取得能力を獲得する前 段階であるが、他児の感情的な反応から相手が苦痛を感じて いることを認識し、介入するための適切な方法を理解してい る可能性が示された。

また本研究では向社会的行動を行った他児と対象児との間 で、引き続いての相互交渉はあまりみられないことが確認さ れた。このことから、2 歳齢では、まだ向社会的行動は行い 手から受け手に対する一方向的なもので、向社会的に振舞っ てもらったからお返しをする、一緒に遊ぶという行動はあま りみられないことがわかった。

今後は争い場面において他児がどのように振舞うのかを調 べることによって、2 歳齢でみられる向社会的なやり取りを さらに詳細に検討する予定である。

\section{引用文献}

Hay, D. F., Castle, J., Davies, L., Demetriou, H., \& Stimson, C. A. (1999). Prosocial action in very early childhood. Journal of Child Psychology and Psychiatry, 40, 905-916.

Kestenbaum, R., Farber L., \& Sroufe, L. A. (1989). Individual differences in empathy among preschoolers: Relation to attachment history. New Directions for Child Development, 44, $51-64$ 